\title{
センサーパッド形状が等尺性膝伸展筋力值に 及ぼす影響
}

\section{The Effect of Sensor Pad Shape on Isometric Knee Extension Strength Measurement}

$\begin{array}{lll}\text { 山崎 } \text { 裕司 }^{1)} & \text { 祖川 稔史 } & \text { 平賀 } \\ \text { 片山跼 }^{1)} \\ \text { 訓博1) }^{1)} & \text { 重島 } \text { 晃史 }^{1)} & \text { 高地 正音1) }\end{array}$

HiROSHI YAMASAKI ${ }^{1)}$, TOSHIFUMI SOGAWA ${ }^{2)}$, YASUSHI HIRAGA ${ }^{1)}$, KUNIHIRo KATAYAMA ${ }^{1)}$, KoJI SHIGESHIMA ${ }^{1)}$, MASATO KOCHI ${ }^{1)}$

1) Department of Physical Therapy, Kochi Rehabilitation Institute: 1139-3 Takaoka-cho, Otu, Tosa-shi, Kochi 781-1102, Japan. TEL +81 88-850-2315

2) Department of Rehabilitation, Dougo Hotspring Hospital

Rigakuryoho Kagaku 24(5): 693-696, 2009. Submitted Mar. 23, 2009. Accepted May 11, 2009.

ABSTRACT: [Purpose] In this study, we investigated the effect of the shape of the sensor pad used in a hand-held dynamometer with a fixed belt on the values of isometric knee extension strength. [Subjects] The subjects were 36 healthy adults: 18 males, 18 females; average age, $20.5 \pm 1.7$ years. [Method] The sensor pads were one in previous use (old pad) and a new one made for this study. The new pad was designed to be thicker, and have a smaller diameter of the curved surface than the old pad. Using the two types of pad we performed measurements of muscle strength on the same day, and compared the measurement values, pain at the time of measurement, and measurement reproducibility. [Results] Values for knee extension strength in the order of the new pad, old pad were $51.4 \pm 14.7$ and $47.3 \pm 14.6 \mathrm{kgf}$ on the first day, and $51.9 \pm 15.3$ and $47.9 \pm 14.0 \mathrm{kgf}$ on the second day, respectively, with the new pad showing a significantly higher value on both days. Pain at the pad contact surface showed a significantly lower value for the new pad. The intraclass correlations for the new and old pads on the first and second days were 0.91 and 0.94, respectively, both showing good intra-rater reproducibility. [Conclusion] The shape of the sensor pad had a substantial effect on the value of isometric knee extension strength and pain at the time of measurement. When measuring knee extension strength, a pad of suitable thickness and shape should be used.

Key words: sensor pad, hand-held dynamometer, pain

要旨：〔目的〕本研究では，固定用ベルトを併用したHand-Held Dynamometerに用いられるセンサーパッドの形状が, 等尺性膝伸展筋力值に与える影響について検討した。〔対象〕健常成人 36 名（男性 18 名，女性 18 名，年齢 $20.5 \pm 1.7$ 歳）の右脚であった。〔万法〕センサーパッドは，従来から使用されていたパッド（旧パッド）と今回作成した新 パッドの 2 種類である。新パッドは旧パッドと比較して, 厚く, 曲面半径が小さく設計されている。2 種類のパッ ドを用いて同日に筋力測定を実施し, 測定值, 測定時疼痛, 測定值の再現性について比較検討した。〔結果〕膝伸 展筋力值は，新パッド，旧パッドの順に 1 日目 $51.4 \pm 14.7 ， 47.3 \pm 14.6 \mathrm{kgf} ， 2$ 日目 $51.9 \pm 15.3 ， 47.9 \pm 14.0 \mathrm{kgf}$ あ゙あ り，両日とも新パッドにおいて有意に高值を示した。パッド接触面での疼痛は，新パッドにおいて有意に低值を示

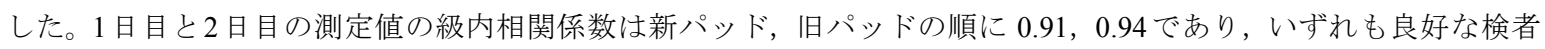
内再現性を示した。〔結語〕センサーパッドの形状は等尺性膝伸展筋力值と測定時の疼痛に強く影響していた。膝 伸展筋力測定に際しては，十分な厚さと適切な形状をもったパッドを利用すべきである。 キーワード : センサーパッド，ハンドヘルドダイナモメーター，疼痛

1) 高知リハビリテーション学院＼cjkstart理学療法学科：土佐市高岡町乙1139-3（テ781-1102） TEL 088-850-2315

2) 道後温泉病院 リハビリテーション科

受付日 2009年3月23日＼cjkstart受理日２009年5月11日 


\section{I.はじめに}

筋力測定機器の中でも Hand-Held Dynamometer (以下, HHD）は，簡便性，低価格性，携帯性，汎用性などの 利点をもった測定機器であり, 臨床に広く普及しつつ ある ${ }^{1,2)}$ 。我々は，信頼性を向上させるために固定用べ ルトを併用したHHDによる等尺性膝伸展筋力測定方法 を考案し, 再現性, 妥当性について報告してきた ${ }^{3-7) 。 ~}$ しかし, 従来のHHDのセンサーパッド部のクッション 素材は薄く, ベルト固定を併用した等尺性膝伸展筋力 測定時には，パッドが接触する下腿遠位部前面に疼痛 を訴える対象者が少なからず存在した。そこで，クッ ション性を向上させるためにパッドを厚くし, さらに 下腿前面との接触面積を増大させるため曲面半径の小 さいパッドを作成した。

本研究では, 等尺性膝伸展筋力測定におけるパッド 厚と形状の変化が測定值, 測定時疼痛, 測定值の再現 性に与える影響について従来のセンサーパッドと比較 検討した。

\section{II. 対象と方法}

1. 対象

健常成人 36 名（男性 18 名, 女性 18 名, 年齢 $20.5 \pm 1.7$ 歳, 身長 $164.8 \pm 7.9 \mathrm{~cm}$, 体重 $55.7 \pm 8.2 \mathrm{~kg}$ ）の右脚 36 脚 である。なお，膝関節の整形外科的疾患や膝関節痛を
有する脚は無かった。対象者には本研究の目的と内容 を説明し，同意を得た後に実験を開始した。

\section{2. 方法}

HHD にはアニマ社製 $\mu$ TasF-1 を用い，椅子坐位下腿 下垂位における等尺性膝伸展筋力を測定した。測定に 際しては，センサーパッドを面ファスナーで下腿遠位 部前面に固定し，下腿後方の支柱と下腿遠位部をベル トで連結した。次いで, ベルトの長さを下腿が下垂位 になるように調節した。測定の際には，膝窩部の圧迫 による疼痛を回避するため, 同部位に折り畳んだバス タオルを敷いた。体幹は垂直位を保つように指示し, 両上肢は体幹前方で組ませた。1回の練習の後，5秒間 の最大努力による膝伸展運動を 2 回実施させ, 最大值 をデータとして採用した。2 回の測定間には 30 秒の休 嚊を設けた。測定中は，センサーパッドのずれを防止 するため検者が前方でパッドを固定した。

センサーパッドには, 従来から使用されていた旧パッ ドと今回新しくアニマ社が作成した新パッドの 2 種類 を用いた（図 1)。旧パッドの曲面半径は $70 \mathrm{~mm}$ で，周 径が $440 \mathrm{~mm}$ の円筒形の下腿遠位部を想定した場合に, 曲面は最も広く皮膚に接触する。新パッドの曲面半径 は25 mmで，周径が $157 \mathrm{~mm}$ の円筒形の下腿遠位部を想 定した場合に，曲面は最も広く皮膚に接触する。最も 肉厚な部分でのパッド厚は，旧パッド $17 \mathrm{~mm}$, 新パッ ド $25.5 \mathrm{~mm}$ である。なお，作成されたパッドが最大筋力
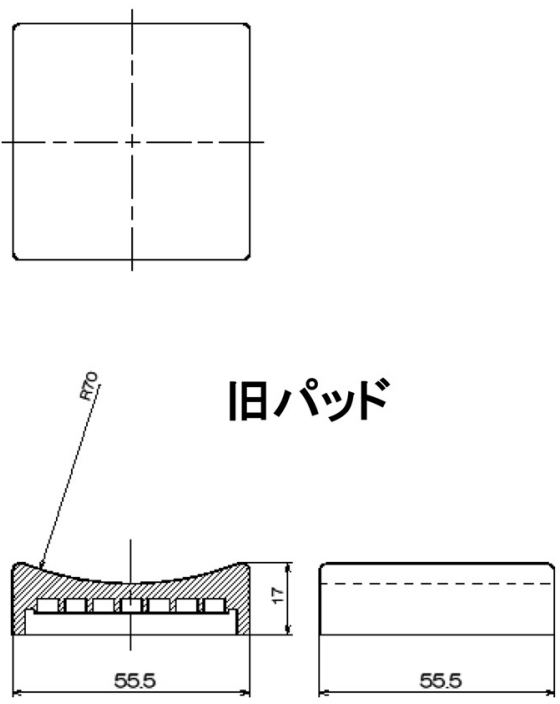

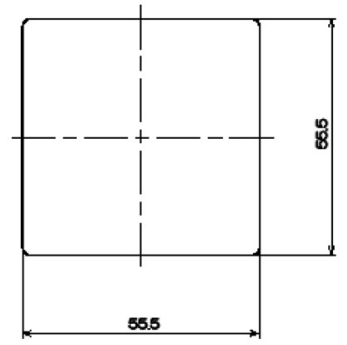

\section{新パッド}

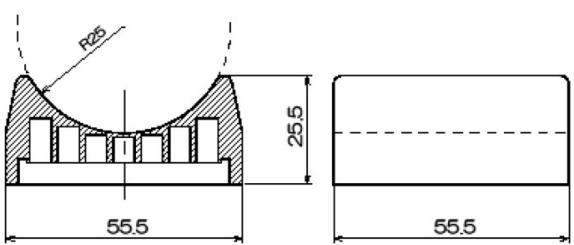

図1 パッドの形状

新パッドでは曲面半径が小さく, シリコンゴムが肉厚となっている. 
值を検出する際のセンサーの感受性に影響を与えない ことをアニマ社から確認した。

新パッド, 旧パッドの測定間には, 3 分以上の休憩を 設けた。各測定後, 下腿遠位部のパッド接触面の疼痛 評価を Numerical Rating Scale（以下，NRS）によって評 価した。なお, 測定順序は無作為に2つのパターンに分 けた。すなわち 18 名は, 1 日目に新パッドから先に測 定を行い, 2 日目は旧パッドから先に行った。残りの18 名はその逆の順序で実施した。

2 種類のパッドにおける筋力值の比較には対応のあ る $\mathrm{t}$ - 検定を, 疼痛の比較にはウィルコクソンの符号付 順位和検定を用いた。再現性の検討には, 級内相関係 数 $(1,1)$ を用いた。疼痛と筋力值の関連について分 析するため 2 種類のパッドの疼痛の差異によって2群に 分類した。ひとつは，2 種類のパッドで疼痛に差がな い，あるいは旧パッドで疼痛が小さいと答えた群。も うひとつは, 新パッドで疼痛が低值を示した群である。 それぞれの群で 2 種類のパッドの違いが筋力值に与え る影響を検討した。筋力值の比較にはウィルコクソン の符号付順位和検定を用いた。いずれの分析も危険率 $5 \%$ 未満を有意水準とした。統計の解析には, SPSSver10J を用いた。

\section{III. 結 果}

膝伸展筋力值は，新パッド，旧パッドの順に 1 日目 $51.4 \pm 14.7 ， 47.3 \pm 14.6 \mathrm{kgf} ， 2$ 日目 $51.9 \pm 15.3 ， 47.9 \pm$ $14.0 \mathrm{kgf}$ であり, 両日とも, 新パッドにおいて有意に高 值を示した $(\mathrm{p}<0.01)$ 。

1 日目と 2 日目の測定值間の級内相関係数は, 新パッ ド，旧パッドの順に $0.91 ， 0.94$ であった。新パッド，旧 パッドとも1日目と2日目の測定值間には有意差を認め なかった。

新パッドと旧パッドにおける膝伸展筋力測定時の疼 痛を示したNRS の中央值 (四分位範囲) は1 日目新パッ ド2（2），旧パッド3（2.25），2 日目新パッド3（2），旧 パッド5（3.25）であり，いずれの測定日においても， 新パッドにおいて有意に低值を示した（ $\mathrm{p}<0.01 ） 。$

2 種類のパッドで疼痛に差がない, あるいは旧パッ ドで疼痛が少ないと答えた測定機会は 2 日間 72 回の測 定中に 13 回あった。その際の筋力值は, 新パッド, 旧 パッドの順に $45.4 \pm 17.0,43.6 \pm 16.0 \mathrm{kgf}$ であり，有意 差を認めなかった。一方, 新パッドで疼痛が弱かった 測定（59回）の筋力值は, 新パッド, 旧パッドの順に $53.2 \pm 13.8,48.2 \pm 13.0 \mathrm{kgf}$ であり, 有意差を認めた $(\mathrm{p}<0.01)$ 。

\section{IV. 考 察}

本研究では, 等尺性膝伸展筋力測定においてセンサー パッドの形状が測定値, 測定時疼痛, 測定值の再現性 に与える影響を検討した。

二日間とも新パッドにおいて有意に筋力は高值を示 した。認められた筋力差は 1 日目平均 $3.1 \mathrm{kgf}, 2$ 日目平 均 $4.0 \mathrm{kgf}$ であり, 測定值の差は旧パッドによる測定值 の 6 から $8 \%$ に相当した。個々の対象者を見た場合, 新 パッドで最大 $11.4 \mathrm{kgf}$ の高值を示し, それは測定值の 27 \%に相当した。旧パッドで疼痛が強くなかった測定時 における 2 種類のパッド間の筋力差は有意ではなかっ た。一方, 旧パッドで疼痛が強く報告された際の筋力 差は $5.0 \mathrm{~kg}$ であり，旧パッド測定值の約 $10 \%$ に相当し た。よって，2種類のパッド間において筋力差が生じた 主要な原因は疼痛の違いにあるものと考えられた。

測定中の疼痛は, 両日とも旧パッドで強かった。測 定時の疼痛は, 測定值を低く抑えるだけでなく, 理学 療法サービスの低下に直結する問題である。アニマ社 製 $\mu$ Tas シリーズに限らず, 従来の HHD のセンサー部 分のパッド厚は薄く, 形状は平面に近い。よって, 発 揮される筋力が大きい場合, 下腿前面の軟部組織に対 する単位面積当たりの圧迫力は大きくなる。現場では, これまでセンサー部分に疼痛を感じた場合, パッドと 下腿遠位部前面の間にタオルなどの緩衝素材を挟むこ とで対応してきた。しかし，これでは測定条件が対象 者や検查者によって異なり, 測定值の信頼性を低下さ せる原因となる。パッドの形状の相違が測定值に与え る影響は決して小さくなく, 筋力測定値の妥当性を向 上寸るためには疼痛を回避し得る十分なパッド厚と適 切な曲面形状を備えることが必要なものと考えられた。

測定值の再現性については, 新パッド，旧パッドと も級内相関係数は 0.90 を越え, 桑原ら ${ }^{8)}$ の基準に照らし 合わせると優秀なものと考えられた。よって, 今回の パッド厚と形状の変化は再現性に影響を与えないもの と考えられた。

最後に, 本研究では健常成人を対象とした。虚弱な 高齢者では, 下腿前面の軟部組織はより薄い。その反 面, 出力される筋力值は小さくなる。これらの要因が 測定時の疼痛や筋力值にどのように影響するのかは明 らかでない。よって, パッド厚と形状の変化が測定值 に与える影響については高齢者や患者群を対象として 追試される必要がある。 


\section{引用文献}

1) 川瀬紘平, 山崎裕司, 中屋久長 - 他 : 筋力測定機器の普及状 況. 高知リハビリテーション学院紀要, 2009, 10: 57-60.

2) 山崎裕司: 機器による筋力測定. 総合リハビリテーション, 2007, 35(7): 724-725.

3) 山崎裕司, 大森圭貢, 長谷川輝美・他 : 固定用ベルトを装着 したハンドヘルドダイナモメーターによって測定した膝伸 展筋力值の妥当性. 高知県理学療法, 2003, 10: 7-11.

4) 山崎裕司, 長谷川輝美 : 固定用ベルトを装着したダイナモ メーターによる等尺性膝伸展筋力の測定一検者内再現性の 検討一. 高知リハビリテーション学院紀要, 2001, 3: 7-11.

5) 加藤宗規, 山崎裕司, 柊 幸伸・他 : ハンドヘルドダイナモ
メーターによる等尺性膝伸展筋力の測定一固定用ベルトの 使用が検者間再現性に与える影響一，総合リ八, 2001, 29: 1047-1050.

6) 山下隆則, 山崎裕司: 固定用ベルトを併用したハンドヘルド ダイナモメーターによる等尺性膝伸展・屈曲筋力測定方法一 外的妥当性の検討一. 高知県理学療法, 2005, 12: 29-32.

7) 平澤有里, 長谷川輝美, 笹 益雄・他 : ハンドヘルドダイナ モメーターを用いた等尺性膝伸展筋力測定の妥当性. 総合リ ハビリテーション, 2005, 33(4): 375-377.

8) 桑原洋一, 斎藤俊弘, 稲垣義明: 検者内および検者間の Reliability（再現性，信頼性）の検討. 呼吸と循環，1993, 41: 945-952. 